\title{
Santri Penghafal Alquran: Motivasi dan Metode Menghafal Alquran Santri Pondok Pesantren Tahfizul Qur'an Sungai Pinang Riau
}

\author{
Rahma Masita ${ }^{1}$, Riche Destania Khirana ${ }^{2}$, Susi Purnamasari Gulo ${ }^{3}$ \\ ${ }^{1}$ Universitas Islam Negeri Sultan Syarif Kasim Riau \\ Email: rahmamasitam@gmail.com
}

\begin{abstract}
This paper analyzes the motivation of students to memorize the Quran and how to memorize the Quran at the Sungai Pinang Islamic Boarding School, Riau. This article is important to study, because in recent decades Islamic boarding schools that have focused their educational programs on memorizing the Quran have increasingly found momentum amid the emergence of new trends in reciting the Quran through da'wah movements initiated by young Muslims. Through field research with data collection techniques through interviews and participant observation, this paper finds that students' motivation to memorize the Quran is at least influenced by their understanding that by memorizing the Quran they can avoid all forms of evil. Furthermore, they believe that memorizing the Quran will bring them to heaven.
\end{abstract}

Keywords: Islamic Boarding School Tahfidzul Quran, Tahfiz Quran, Motivation to memorize the Quran

\begin{abstract}
Abstrak: Tulisan ini menganalisis tentang motivasi santri dalam menghafal Alquran serta cara menghafalkan Alquran di Pondok Pesantren Sungai Pinang Riau. Tulisan ini penting dikaji, karena dalam beberapa dekade belakangan ini pesantren-pesantren yang memfokuskan program pendidikannya pada penghafalan Alquran semakin menemukan momentumnya di tengah munculnya tren-tren baru dalam melafalkan Alquran melalui gerakan-gerakan dakwah yang diinisiasi oleh anakanak muda Muslim. Melalui penelitian lapangan dengan teknik pengumpulan data melalui wawancara dan observasi partisipan, tulisan ini menemukan motivasi santri dalam menghafalkan Alquran setidaknya dipengaruhi oleh pemahaman mereka bahwa dengan menghafalkan Alquran mereka dapat terhindar dari segala bentuk keburukan. Lebih jauh, mereka meyakini bahwa menghafal Alquran akan membawa mereka masuk ke dalam surga.
\end{abstract}

Kata kunci: Pesantren Tahfizul Qur’an, Tahfiz Qur’an, Motivasi Menghafal Alquran

\section{Pendahuluan}

Artikel ini membahas tentang santri penghafal Alquran. Tidak sedikit pondok pesantren di Indonesia yang memfokuskan program pendidikannya pada hafalan Alquran (Tahfizul Qur'an). Secara normatif, menghafal Alquran hukumnya fardhu kifayah. Secara etimologi tahfiz Alquran terdiri dari dua suku kata, yaitu tahfiz dan Alquran, yang keduanya mempunyai arti berbeda. Pertama, tahfiz berasal dari bahasa arab yaitu hafiza-yahfadzuhifdzan yang berarti menghafal. Kedua, Alquran berasal dari bahasa Arab yaitu qara-a yaqra$u$, yang artinya membaca. Menurut Abdul Aziz Abdul Rauf, definisi tahfiz atau menghafal adalah proses mengulang sesuatu, baik dengan membaca atau mendengar. Kata hafiz mengandung arti penekanan dan pengulangan pemelihara, serta kesempurnaannya. Ia juga bermakna mengawasi (Sepudin, 2015: 23). 
Memang sudah banyak sarjana yang meneliti tentang tahfiz Alquran seperti yang ditulis oleh Iffah Alawiyah (2004), yang berjudul "Efektivitas Penghafal Alquran (Studi Kasus di Pondok Pesantren Anak-anak Yambu' Alquran Krandon Kudus Jawa Tengah). Alawiyah lebih memfokuskan pada efektivitas penghafal Alquran di kalangan anak-anak. Senada dengan Alawiyah, Lailatul Maghfiroh (2009) juga meneliti tentang santri penghafal Alquran di Asrama MI Wahid Hasyim Gaten Condongcatur Depok Sleman Yogyakarta. Maghfiroh lebih memfokuskan pada faktor penyebab kejenuhan santri dalam menghafal Alquran. Temuan penting dari penelitian Maghfiroh bahwa ada dua faktor yang menyebabkan kejenuhan santri dalam menghafal Alquran yaitu, pertama, faktor yang berasal dari dalam diri santri yang berupa keletihan secara fisik dan mental. Kedua, faktor yang berasal dari luar santri, seperti banyaknya kegiatan yang diikuti, tempat belajar yang monoton, banyaknya peraturan dan kesibukan di kelas.

Studi-studi sebelumnya cenderung mengkaji penghafal Alquran dalam konteks kegagalan, kejenuhan, strategi pembinaan. Artikel ini menampilkan hal yang berbeda dengan fokus membahas motivasi santri dalam menghafal Alquran. Dalam artikel ini penulis menempatkan motivasi sebagai cara santri dalam menghafal Alquran. Penelitian ini penting dilakukan untuk melihat bagaimana motivasi santri dalam menghafal Alquran dengan baik. Untuk menjawab pertanyaan penelitian tersebut, artikel ini dibagi menjadi 5 bagian. Pada bagian pertama, artikel ini menjelaskan latar belakang yang menjadi fokus kajian ini. Bagian kedua artikel ini mendeskripsikan tentang profil pondok pesantren yang menjadi studi kasus penelitian ini, dan bagian terakhir membahas tentang motivasi santri untuk menghafal Alquran.

\section{Metode}

Penelitian ini merupakan penelitian lapangan (field research) dengan pendekatan kualitatif. Selama di lapangan, kami mewawancarai sejumlah santri dan alumni yang terlibat langsung dalam menghafal Alquran di Pesantren Tahfizul Qur'an Sungai Pinang Riau. Selain itu, untuk memperkaya data penelitian dan mendapatkan gambaran yang utuh tentang aktivitas pembelajaran di pesantren tersebut terutama yang berkaitan dengan program tahfiz, peneliti menggunakan data observasi partisipan atau pengalaman langsung. Observasi partisipan ini berlangsung telah lama sebelum penelitian ini dilakukan, karena salah satu anggota peneliti merupakan alumni dari pesantren tersebut. Selanjutnya, data-data tersebut diolah berdasarkan metode analisis Miles dan Huberman yang meliputi reduksi data, penyajian dan kesimpulan (Sugiono, 2012: 94-95).

\section{Hasil dan Pembahasan}

\section{Pesantren Tahfizul Qur'an Sungai Pinang}

Sejarah berdirinya Pondok Pesantren Tahfizul Qur'an Sungai Pinang adalah karena adanya keprihatian masyarakat terhadap pemahaman, cara baca, dan hafalan Alquran yang rendah. Pesantren ini didirikan tahun 1998 oleh putra Kampar Abuya Sofyan yang merupakan tamatan dari Pondok Pesantren Darussalam Kabun 13 koto Kampar. Kemudian ia 
melakukan kerjasama dengan Pondok Pesantren Darussalam Kabun 13 Koto Kampar dalam rangka memberikan pengalaman berdakwah kepada santri melalui program pengabdian.

Lingkungan di sekitar Pondok Pesantren Tahfizul Qur'an Sungai Pinang adalah masyarakat petani. Animo masyarakat terhadap Pesantren Tahfizul Qur'an Sungai Pinang sangat tinggi sehingga pada setiap tahun ajaran baru banyak para orang tua memasukkan anak mereka ke Pesantren Tahfizul Qur'an. Penyeleksian calon santri baru sangat diperlukan untuk menjaga kualitas pendidikan yang sedang berlangsung serta lulusan yang mampu membaca dan menghafal Alquran. Seleksi penerimaan santri meliputi tes akademik, tes kepribadian dan tes kemampuan agama. Tes ini berguna untuk menyeleksi dan mengelompokkan para santri dan santriwat baru dalam pembelajarannya. Agar mereka tidak merasa susah dalam mengikuti alur dari pelajaran yang akan diajarkan kepada mereka. Para ustadz maupun ustazah akan dengan mudah mengajarkannya. Rini Maya Sari, seorang alumni yang kami wawancarai, dia mengatakan:

"Saya merasa senang melihat masih banyak yang memasukkan anak-anaknya untuk di sekolah kan di pondok pesantren yang berbasis Qur"eani. Sehingga mengingatkan saya 6 tahun yang lalu, meski dengan raut wajah tidak senang di tempakan di pondok tahfizul Alquran. Tapi sekarang saya merasa bersyukur akan hal itu."

Metode Tahfizul Qur'an menggunakan metode talaqqi, yaitu metode menghafal dengan cara santri membaca Alquran dihadapan ustadz sampai ucapannya benar. Setelah benar barulah santri tersebut menghafalnya sendiri. Proses menghafal masing-masing santri tersebut berbeda-beda sesuai dengan kemampuan dan kenyamanan mereka masing-masing. Rata-rata pengulangan bagi santri yang potensinya bagus, satu ayat diulangi lima sampai sepuluh kali sesudah hafal. Waktu menghafalnya dibagi menjadi tiga. Waktu menambah hafalan pagi hari atau setelah subuh. Waktu murajaah atau mengulang-ngulang hafalan setelah ashar dan maghrib. Kendala dalam menghafal Alquran dikarenakan mereka pada pagi harinya sekolah formal sehingga perolehan hafalan tidak secepat bagi mereka yang khusus untuk menghafal Alquran saja.

Pendidikan Alquran, secara khusus diatur pada pasal 24 Peraturan Pemerintah no. 55 tahun 2007 tentang Pendidikan Agama dan Pendidikan Keagamaan. Dalam peraturan tersebut dijelaskan bahwa satuan pendidikan Alquran bertujuan meningkatkan kemampuan peserta didik dalam membaca, menulis, memahami, dan mengamalkan kandungan Alquran. Satuan pendidikan agama yang dimaksud adalah Taman kanak-kanak Alquran(TKQ), Taman Pendidikan Alquran (TPQ), Ta'limul Qurean lil Aulad (TQA). Dan lainnya yang dilaksanankan secara berjenjang.

Penyelenggaraan pendidikan Alquran ini dapat diselenggarakan di masjid, musala, atau tempat lainnya yang memenuhi syarat. Sistem pembelajaran Alquran ini disusun dalam sebuah sistem pembelajaran yang sistematis (kurikulum), yaitu membaca, menulis, dan menghafal Alquran, tajwid, serta menghafal doa-doa utama. Dipandu oleh pendidik yang berkompeten dalam hal tersebut, minimal lulusan diniyah menengah ke atas atau yang sederajat yang dapat membaca Alquran dengan tartil dan menguasai teknik pengajaran Alquran. 
Pendidikan Alquran dalam sejarah pendidikan Islam di Indonesia sudah diselenggarakan oleh orang tua, guru agama Islam, dan tokoh-tokoh agama Islam. Tidak jarang di pedesaan masih terlihat anak-anak Muslim beramai-ramai mengunjungi surau ataupun guru ngaji mereka selepas Maghrib. Berbeda dengan desa, di perkotaan Indonesia banyak terlihat anak-anak Muslim masuk ke pendidikan Alquran seperti MDA, TPQ, dan lainnya.

Jika ditinjau lebih awal, utamanya sebelum lahirnya Peraturan Pemerintah No 55 tahun 2007, bahkan sebelum kemerdekaan RI, sistem pendidikan Alquran sudah ada dan dipraktekkan dalam keluarga, baik dilakukan secara mandiri maupun berkelompok yang dipandu seorang kyai atau guru. Dalam perkembangannya kemudian berkembang istilah TKA, TKQ, TPA, TPQ, TQA, dan lainnya yang semakin berkembang di tengah masyarakat. Kehadiran taman pendidikan Alquran itu biasanya bermula dari kegelisahan orangtua, tokoh agama dan pemerintah terhadap penurunan kemampuan generasi dalam membaca dan memahami kitab suci Alquran serta penerapannya dalam kehidupan sehari-hari. Oleh karena itu, pada tahun 1982 diterbitkan SKB Mendragri dan Menteri Agama No 128 dan 44 A tahun 1982 tentang Usaha Peningkatan Kemampuan Baca Tulis Huruf Alquran bagi umat islam dalam rangka peningkatan penghayatan dan pengamalan Alquran dalam kehidupan seharihari.

Adapun faktor pendukung yang bisa memudahkan dalam penyelenggaraan tahfizh adalah tersedianya fasilitas yang memadai, ustadz yang kompeten dalam bidang tahfizh tersebut, dan juga peserta didik yang memiliki potensi bagus. Adapun faktor penghambat penyelenggaraan tahfizh yaitu minimnya tenaga pengajar dibidang tahfizh Alquran dan penghambat yang lainnya yaitu sering bergantinya guru pengajar tahfizh dikarenakan belum mempunyai SDM yang tetap.

Tahfizul Quran Sungai Pinang adalah salah satu pondok yang menginginkan anak didik menjadi Insan teladan dalam hal moral, spritual maupun intelektual, maka dari itu apapun faktor yang mendukung dan dapat menjadikan hal tersebut terwujud akan dipenuhi dan lakukan, akan tetapi dengan integrasi dari berbagai faktor yang mendukung dan dengan kekuatan SDM yang handal dan tentunya izin dan kuasa Allah SWT, maka semua akan terwujud sesuai dengan harapan dan keinginan kita semua.

Bagi orang-orang beriman mengambil manfaat dari Alquran tidak saja dapat di raih melalui pengalaman, tetapi juga melalui pembacaannya. Menurut Rasulullah Saw, setiap orang yang membaca Alquran akan mendapat satu kebaikan dari tiap huruf yang dibacanya, bahkan boleh saja ditambah dengan 10 kebaikan (Su'aib dan Muhammad, 2011:67). Intensif, terarah, terdidik dan fokus adalah salah satu kekuatan dalam memberikan pelayanan pendidikan bagi santri, baik di bidang formal maupun agama, sehingga tidak heran jika banyak prestasi yang sudah didapatkan oleh santri Tahfizul Quran Sungai Pinang ini baik untuk SMP tahfiz maupun SMA tahfiznya baik ditingkat kecamatan maupun kabupaten. Hafal 10 juz adalah target untuk santri jika lulus nantinya, walau seringkali banyak yang melampaui target hingga 20 juz. Hal ini merupakan bukti keseriusan pesantren dalam mendidik dan memberikan pendidikan yang terbaik untuk santri. 
Masa-masa remaja adalah masa-masa di mana anak mulai tumbuh dewasa dan rentan akan pengaruh dunia luar, sehingga kewaspadaan orang tua dalam menjaga dan mengawasinya pun harus extra hati-hati karena salah pergaulan akan mempengaruhi masa depan mereka. Sehingga sudah selayaknya jika orang tua merasa kurang mampu dalam mengawasi dan menjaganya, alternatif pilihannya adalah di pondok pesantren dimana pola pengawasan, pola pengajaran pola, pola pendapingan, pola bimbingan, pola pelayanan, pola hidup dan pola keseharian sudah terencana dan terprogram dengan baik. Para orang tua yang menginginkan anaknya untuk belajar tahfiz Alqurantentunya memiliki harapan juga agar anaknya belajar ilmu agama, bahkan menginginkan anaknya menjadi anak yang cinta Alquran.

Evaluasi setor harian mingguan, bulanan dan semesteran merupakan langkah yang dimaksudkan agar santri selalu rutin dan rajin menghafal sehingga diharapkan santri mencapai target yang ditetapkan. Adapun aspek-aspek yang di nilai dalam evaluasi pembelajaran tersebut adalah :1) parsitipasi aktif dan keseriusan dalam menghafal;2) tajwid dan fashahah;3) akhlak terhadap pembimbing;4) akhlak terhadap Alquran, dan;5) kelancaran hafalan.

"Terkadang sebelum saya menyetorkan ayat hafalan, saya murojaah dan memantapkan hafalan terlebih dahulu. Karena saya lebih berfokus menjaga dengan tambahan yang tidak terlalu membebankan saya. Saya senang mengulang kembali hafalan saya" Jawab Fitri Nurfadhilah (santriwati) ketika kami wawancarai.

Pengurus pesantren hanya bisa berusaha semaksimal kemampuannya, tentunya tanpa dukungan dan parsitipasi dari wali santri dan berbagai pihak yang terkait tentu semuanya tidak akan berjalan dengan baik. Banyak sekali kekurangan yang harus harus di perbaharui, harapan ke depan Pesantren Tahfizul Qu"an dapan menjadi Banch Mark sekolah berbasis baik tingkat daerah maupun Nasional.

Artikel ini menunjukkan bahwa Pesantren Tahfizul Qur'an ini didirikan dalam upaya menjawab tantangan sekolah yang berbasis Qur'an yang saat ini sangat jarang ditemukan, padahal keberadaannya sangat dibutuhkan dalam upaya untuk meningkatkan kualitas anak dan sisi spiritual, moral dan intelektual selain berbasis Qur'an. pendidikan di Pesantren Tahfizul Qur'an juga dipadukan dengan kurikulum pendidikan Nasional, dari perpaduan pendidikan Qur"an dan kurikulum pendidikan Nasional peserta didik diharapkan menjadi Insan yang unggul dibidang imtak dan iptek. Untuk hari-hari libur mereka mengadakan percepatan hafalan Alquran dengan tujuan mengefektifkan perolehan hafalan Alquran. Begitu juga untuk memperoleh hafalan yang berkualitas mengadakan inovasi pembelajaran diantaranya tasmi, membaca perkelompok per ayat, bimbingan, dan perlombaan tahfizh Quran. Meskipun berbeda misi dengan Pesantren lain, Tahfizul Qur'an Sungai Pinang tampaknya memiliki pola pengajaran menghafal yang sama dengan Pesantren yang ada di Kabupaten Kampar. Dengan mendidik santri menjadi hafiz Alquran 30 Juz dengan itqan.

\section{Tahfidz Alquran}

Kata tahfiz merupakan bentuk masdar dari haffaza, asal dari kata hafiza-yahfazu yang artinya "menghafal". Hafiz menurut Quraisy Syihab terambil dari tiga huruf yang 
mengandung makna memelihara dan mengawasi. Dari makna ini kemudian lahir kata menghafal, karena yang menghafal memelihara dengan baik ingatannya. Juga makna "tidak lengah", karena sikap ini mengantar kepada keterpeliharaan, dan "menjaga", karena penjagaan adalah bagian dari pemeliharaan dan pengawasan. Kata hafiz mengandung arti penekanan dan pengulangan pemelihara, serta kesempurnaannya. Ia juga bermakna mengawasi.

Sedang kata Alquran merupakan kalamullah yang diturunkan kepada Nabi Muhammad Saw. melalui perantaraan Malaikat Jibril as. yang ditilawahkan secara lisan, diriwayatkan kepada kita secara mutawatir, dan membacanya merupakan ibadah. Menurut Al-Jurjani yang diturunkan kepada Rasulullah SAW. ditulis dalam mushaf dan diriwayatkan secara mutawattir tanpa keraguan. Ada beberapa bagian atau unsur penting dalam pengertian Alquranyaitu: membaca Alquranbernilai ibadah. Nabi Muhammad bersabda: "Aku tidak mengatakan aliflam mim satu huruf tetapi alif satu huruf, lam satu huruf, mim satu huruf dan satu kebaikan nilainya 10 kali lipat.

Tahfiz Alquranadalah proses untuk memelihara, menjaga dan melestarikan kemurnian Alquranyang diturunkan kepada Rasulullah SAW. di luar kepala agar tidak terjadi perubahan dan pemalsuan serta dapat menjaga dari kelupaan baik secara keseluruhan maupun sebagiannya. Sedangkan program pendidikan menghafal Alquranadalah menghafal Alquranadalah program menghafal Alqurandengan mutqin (hafalan yang kuat) terhadap lafadz-lafadz Alqurandan menghafal makna-maknanya dengan kuat yang memudahkan untuk menghindarkannya setiap mengahadapi berbagai masalah kehidupan, yang mana Alquransenantiasa ada dan hidup di dalam hati sepanjang waktu sehingga memudahkan untuk menerapkan dan mengamalkannya (Al-Lahim, 2008:19).

Keikhlasan yang sesungguhnya adalah dengan menghilangkan pikiran tentang ikhlas itu sendiri. Siapa yang baik ikhlasnya, berarti sikap ikhlasnya itu memerlukan suatu keikhlasan, yakni pengosongan tujuan taqqarub kepada Allah dari segala celaan noda dalam bebagai bentuk ketaatan (Saefudin, 2005: 47). Allah berfirman, "padahal mereka tidak disuruh kecuali supaya menyembah Allah dengan memurnikan ketaatan kepada-Nya dalam menjalankan agama dengan lurus." (Qs Al Bayyinah (98):5) Allah berfirman juga "barang siapa mengharap perjumpaan dengan Tuhannya, maka hendaklah dia mengerjakan amal shalih dan jangan mempersekutukan seorang pun dalam beribadah kepada Tuhannya." (Qs Al Kahffi (18):110) Al Fudhail pernah berkata, "meninggalkan suatu pekerjaan lantaran manusia adalah perilaku riya, melakukan pekerjaan karena manusia adala perbuatan syirik, sedangkan keikhlasan adalah semata-mata karena Allah dan terbebas dari kedua hal itu (riya ${ }^{e e}$ dan syirik)" Orang yang ikhlas adalah orang yang melupakan makhluk dan menetapkan pandangan hanya kepada sang khalik, dan hanya menginginkan keridhan Allah dalam segala perbuatan, tindakan serta gerakannya secara lahir maupun batin, tidak peduli dengan pujian maupun celaan orang lain selama berada dalam kebenaran. Namun jika ada orang lain yang menyanjungnya, maka ia akan memuji Allah dan bersyukur kepada-Nya karena telah menutup aibnya, dan tetap memuji Allah takkala orang lain melihat kebaikan yang ia lakukan (Umar, 2009: 33). Barang siapa yang mau merenungkan Alquranmerengkan sebelum dan sesudah ayatnya, dan mengetahui apa yang dimaksud oleh Alquran, ia akan dapat memahami 
makna yang dikehendaki dan mengetahui petunjuk dan risalah yang diberikan, serta mengetahui mana yang menyimpang. (Ibnu Taimiyyah, Majmu ${ }^{e e}$ Alfatawa, 15/94) Saya benar-benar menganjurkan agar pemuda terus merenungkan ayat-ayat Alqurandan memahami maknanya. Karena sesungguhnya Alquran itu di turunkan untuk umat manusia untuk direnungkan ayat-ayatnya dan dijadikan sebagai pelajaran. Sebab, tidak ada gunanya membaca lafadz-lafadz Alquran tanpa memahami maknanya. Dan jika anda menemui kesulitan dalam memahaminya maka bertanyalah kepada ahlinya. (Ibnu Utsaimin, Liqa ${ }^{\text {ee } a t u l ~}$

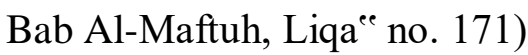

Allah SWT, telah menjamin pemeliharaan Alquranini dengan ungkapan yang tegas. Di antara perangkat untuk memeliharanya adalah menyiapkan orang yang menghafalnya pada setiap generasi. Mereka telah menghafal Alqurandengan baik sebelum mereka berusia sepuluh tahun, dan mungkin mereka menghafalnya pada usia yang lebih muda lagi. Di Bangladesh, seorang anak telah hafal Alquransaat ia berusia sembilan tahun, ketika mendengar hafalanya ternyata hafalannya sangat bagus sekali.

Ahsin W. Al-Hafidz mendefinisikan menghafal Alquranadalah langkah awal untuk memahami kandungan ilmu - ilmu Alquran yang dilakukan setelah proses membaca dengan baik dan benar. Keutamaan menghafal Alquranbanyak hadist Rasulullah saw yang mendorong untuk menghafal Alquranatau membacanya di luar kepala, sehingga hati seseorang muslim tidak kosong dari sesuatu bagian dari kitab Allah SWT. Rasulullah memberikan penghormatan kepada orang-orang yang mempunyai keahlian dalam membaca Alquran dan menghafalnya, memberitahukan kedudukan mereka, dan mengedepankan mereka dibandingkan dengan orang lain. Abu Hurairah ra, mengatakan bahwa Rasulullah mengutus satu utusan yang terdiri dari beberapa orang. Kemudian Rasulullah mengecek kemampuan membaca dan hafalan Alquranmereka. Setiap laki-laki ditanyakan seberapa banyak hafalan Alquran mereka (Hafidz, 2004: 61).

Adab-adab penghafal Alquran: Pertama, Menjauhi dan menghindari diri dari perbuatanperbuatan yang menjadikan Alquran sebagai sumber penghasilan pekerjaan dalam kehidupannya. Imam Abu Sulaiman al-Khatabhi menceritakan larangan mengambil upah atas pembacaan Alqurandari sejumlah ulama, diantaranya Az-Zuhri dan Abu Hanifah. Sejumlah ulama mengatakan boleh mengambil upah bila tidak mensyaratkannya, yaitu pendapat dari Ibnu Sirin, Hasan Basri, dan Sya bi. Imam Atha ${ }^{e e}$, Imam Syafieci, Imam Malik, dan lainnya berpendapat boleh mengambil upah, jika disyaratkan dan dengan akad sewa yang benar. Kedua Memelihara bacaannya Ulama salaf mempunyai kebiasaan-kebiasaan yang berbeda dalam jangka waktu pengkhataman Alquran. Ibnu Abi Daud meriwayatkan dari sebagian ulama salaf, bahwa mereka menghatamkan Alquran itu dalam setiap bulan, ada juga yang khatam setiap sepiluh hari, ada juga seminggu menghatamkan Alquran, dan ada juga dalam waktu sehari semalam

Di antara beberapa hal yang harus dipenuhi sebelum seseorang memasuki periode menghafal Alquran: Pertama, Mampu mengosongkan benaknya dari pikiran-pikiran dan teori-teori, atau permasalahan-permasalahan yang sekiranya mengganggunya dalam menghafal. Mengosongkan pikiran lain yang sekirannya mengganggu dalam proses menghafal merupakan hal yang paling penting. Dengan kondisi yang seperti ini akan 
mempermudah dalam proses menghafal Alquran karena benar-benar fokus dalam menghafal Alquran. Dua, Niat yang ikhlas. Niat adalah unsur penting dan paling utama dalam hal menghafal Alquran, sebab apabila seseorang melakukan sebuah perbuatan tampa dasar mencari keridhoan Allah semata, maka amalan dan perbuatannya akan sia-sia belaka. Tiga, Izin dari orang tua, Wali atau suami.

Semua anak yang hendak mencari ilmu dan menghafal Alquran, sebaiknya terlebih dahulu meminta izin kepada kedua orang tua dan kepada suami (bagi wanita yang sudah menikah). Sebab hal itu akan menentukan dan membantu keberhasilan dalam meraih cita-cita untuk menghafal Alquran. Empat, Tekat yang kuat dan bulat. Tekat yang kuat dan sunguhsungguh akan mengantarkan seseorang ke tempat tujuan, dan akan membentengi atau menjadi perisai terhadap kendala-kendalan yang mungkin akan datang merintanginya. Sebagaimana firman Allah (Qs. Al-isra ${ }^{\text {ec }}$ 19). Lima, Sabar. Keteguhan dan kesabaran merupakan faktor-faktor yang sangat penting bagi orang yang sedang dalam proses menghafal Alquran. Karena dalam proes menghafal tersebut kita akan menemukan banyak masalah dan kendala. Enam, Istiqamah (konsisten), yaitu tetap menjaga keajekan dalam menghafal Alquran. Dengan kata lain harus senantiasa menjaga kontiniutas dan efisiensi terhadap aktu dalam menghafal Alquran. Tujuh, Menjauhkan diri dari maksiat dan perbuatan tercela. Yang mana perbuatan tersebut merupakan perbuatan yang harus dijauhi, bukan saja oleh orang yang sedang menghafal Alquran tetapi semua kaum muslimin lain nya. Karena keduanya mempengaruhi terhadap perkembangan jiwa dan mengusik ketenangan hati. Sehingga akan merusak keistiqamaan dan dan konsentrasi yang telah dibina dan dilatih sebagus mungkin. Delapan, Mampu membaca dengan baik. Mampu membaca Alquran dengan tajwid dan makhraj karena akan mempermudah penghafal untuk melafadzkannya

Badwil menyebutkan juga tentang kaidah-kaidah umum yang diharapkan bisa membantu mereka yang ingin menghafal Alquran, agar mereka mendapat kedudukan yang tinggi atau sebagian dari nya jika tidak dicapai seluruhnya. Tekad itu harus datang kepada seorang yang memiliki ketangguhan. Beberapa kaidah penting yang harus diperhatikan adalah: Pertama, konsumsi dengan satu mushaf Alquran. Yang bisa membantu hafalan secara sempurna adalah jika penghafal menjadikan mushaf khusus tidak diganti secara mutlak. Karena manusia dapat mengingat dan melihat gambaran ayat juga posisi-posisi ayat dalam mushaf bisa melekat dalam pikiran. Dua, berguru pada ulama yang hafiz. Dalam menghafal Alquran sangat penting agar ilmu yang diperolehnya benar (shahih), sanadnya bersambung pada NabiMuhammad SAW, sehingga kebenarannya terjamin. Tiga, memilih dan mengatur waktu dengan baik. Ada beberapa waktu yang dianggap baik untuk menghafal Al-Quran, diantaranya waktu sebelum datang fajar, setelah sholat subuh dan waktu diantara magrib dengan isya. Seorang penghafal juga harus pandai untuk mengatur waktu untuk menjaga kelancaran hafalannya. Empat, menentukan target hafalan setiap hari. Bagi yang ingin menghafal Alquran wajib menentukan batasan hafalan yang disanggupinya setiap hari. Lima, mengulangi secara rutin. Pengulangan bertujuan untuk menjaga hafalan. Seorang penghafal Alquran harus mempunyai wirid rutin, minimal 1 juz setiap hari dengan pengulangan rutin dan pemeliharaan yang berkesinambungan hafalan akan terus langgeng. Enam, menggunaan 
tahun-tahun yang tepat untuk menghafal. Tahun yang tepat untuk menghafal Alquran yang benar-benar telah disepakati yaitu dari umur 5 tahun hingga kira-kira 23 tahun.

Ada sebagian dari saudara kita yang beragama kristen dengan serius berusaha menghafal Alquranatau beberapa juz dari Alquran. Dan berharap agar anak merekapun menghafalnya di usia dini. Hal ini diceritakan sendiri oleh Dr. Nazhmi Lukas, seorang sastrawan Koptik Mesir, tentang dirinya dalam pembukaan bukunya yang terkenal, Muhammad Risalah dan Rasul. Ia menceritakan bagaimana bapaknya mengirimnya kepada salah seorang syekh yang buta dan amat baik hafalannya di kota Suez. Bapakya meminta syekh itu untuk mengajarkan anaknya menhafal Alquran dan dasar-dasarnya (Zainu, 2006: 190).

Pemimpin Politik Koptik Mesir yang terkenal, Makram Ubeid, yang menghafal Alqurandengan jumlah yang banyak, dan ia dengan lincah mengutip dari Alquran dalam pidato-pidato, artikel, pembelaannya dalam persidangan, dan kata-kata Alquranyang ia gunakan itu memberikan keindahan dalam ucapan-ucapannya dan memberikan kekuatan yang tidak dapat diberikan oleh sumber lainnya selain Alquran.

Di antara manfaat menghafal Alquran pada masa kanak-kanak adalah meluruskan lidah, membaca huruf dengan benar dan tepat Maharijul Hurufnya, hingga membaca Alquran dengan fasih tidak seperti orang awam. Sayangnya, sebagian pendidik yang kurang faseh dalam membaca huruf jim, tidak mengeluarkan lidah saat membaca huruf tsa, dzal, zha, dan lainnya, tidak menebalkan huruf izhar yang terkenal dalam kha, shad, dhadh, tha, zha, ghain, dan qaf, kapan harus menebalkan huruf $r a$ dan kapan menipiskannya, juga seperti huruf lam dalam kata Allah, dan kapan ditipiskan. Dengan menghafal Alqurandan membacanya dengan baik sejak kecil, membuat lidah menjadi lembut sehingga itu menjadi tabiat yang kedua. Oleh karena itu, seseorang yang ingin menghafal Alquran dengan cepat dan lancar hendaknya memiliki hati yang bersih dari dosa dan maksiat. Ia mesti sering melakukan taubat dan riyadhah, mendekatkan diri kepada Allah dengan cara memperbanyak qiyamul lail, membaca Alquran, berpuasa, berdzikir, menjauhi maksiat, dan ikhlas hati dalam menghafal Alquran. Selain itu, ia benar-benar bersungguh-sungguh dalam menghafal Alquran dengan menjadikan aktivitas menghafal sebagai rutinitas sehari-hari dan selalu mengulang-ulang hafalannya. Dengan cara demikian, maka baginya ada peluang yang besar untuk menjadi hafidz dalam waktu yang cepat.

Artikel ini menunjukkan bahwa tahfiz Alquran jaminan kemuliaan antara lain bahwa orang yang menghafal Alquran akan diberi syafaat baginya, menghafal Alquran merupakan sebaik-baik ibadah, selalu dilindungi malaikat, mendapat rahmat dan ketenangan, mendapat anugerah Allah, dan menjadi hadiah bagi orang tuanya. Terdapat beberapa manfaat dan keutamaan tentang kedudukan para penghafal Alquran. menghafal Alquran berarti menjaga otentisitas Alquran yang hukumnya fardlu kifayah, sehingga orang yang menghafal Alquran dengan hati bersih dan ikhlas mendapatkan kedudukan yang sangat mulia di dunia dan di akhirat, karena mereka merupakan makhluk pilihan Allah. Maka kemudahan yang diberikan Allah kepada kaum muslimin yang menghafal Alquran merupakan karunia-Nya agar Alquran tetap terjaga kemurnniannya sepanjang zaman. 


\section{Motivasi Menghafal Alquran}

Menghafal Alquran yang utama adalah kemauan sendiri tanpa adanya paksaan dari orang tua atau orang lain. Kemauan atau niat merupakan faktor pendorong yang dilatar belakangi oleh keyakinan akan nilai-nilai spritual. Niat dalam menghafal Alquran harus ikhlas semata-mata karena Allah SWT. Bukan mengharapkan pujian dari orang lain. Niat sangat berpengaruh pada hasil yang diperoleh seseorang dalam setiap perbuatannya. Faktor pendukung lainnya adalah motivasi atau dorongan dari orang tua, dan dorongan dari diri sendiri karena ingin membahagiakan orang tua. Untuk mengatasi ketika ada santri yang sudah mulai malas menghafal dan setoran yaitu dengan memberikan motivasi seperti menceritakan orang-orang yang menghafal Alquran, kedua orang tuanya penghafal Alquranmendapat kemulian seperti dalam hadits HR. Al-Hakim (siapa yang membaca Alquran, mempelajarinya dan mengamalkannya, maka dipakaikan mahkota dari cahaya pada hari kiamat. Seperti cahaya matahari dan kedua orang tuanya dipakaikan dua jubah kemulian yang tidak pernah di dapatkannya di dunia).

Dan sesungguhnya telah Kami mudahkan Alquran untuk pelajaran, maka adakah orang yang mengambil pelajaran? (Qs. al-Qamar 54: 17). Sebagian ayat-ayat tentang garansi dari Allah langsung bahwa Alquranakan selalu terjaga. Salah satu realisasinya, Allah memberi kemudahan kepada orang-orang yang ingin menghafal Alquran. Jika ada di kalangan manusia yang berusaha untuk menghafalnya, maka Allah telah mengabarkan bahwa Allah sendiri yang akan memberi pertolongan dan kemudahan bagi mereka (Hamam, 2008: 13). Terjaganya Alquran pada hafalan-hafalan umat Islam yang telah mampu menghafal satu Alquran penuh. Ayat ini juga menjadi motivasi bagi siapa saja baik individu maupun suatu lembaga pendidikan dalam menyelenggarakan program menghafal Alquran secara sistematis dan terukur dimana target hafalan Alquran30 Juz bisa terwujud (Fachrudin, 2017).

Di Pesantern Tahfizul Qur'an waktu yang baik untuk menghafal Alquran adalah di pagi hari sebelum kegiatan yang lain dimulai, misalnya jam 06.00 sampai jam 07.00. Serta mengulang hafalan setelah selesai shalat fardhu untuk mempelancar hafalan ayat. Selain pelajaran rutin dan mengaji, santri juga di bekali dengan berbagai macam kegiatan ekstrakurikuler agar bakat-bakat yang ada dapat tersalurkan selain juga untuk mengurang rasa kejenuhan bagi santri dan santriwati.

Adapun kegiatan ekstrakurikuler baik dibidang olahraga maupun seni. Para santri sangat antusias dalam mengikuti kegiatan tersebut. Karena sejatinya mereka adalah anak sekolah yang harus menikmati masa sekolah layaknya sekolah lainnya.

Setiap tahunnya mereka mengadakan perlombaan ektrakurikuler dibidang olahraga yakni perlombaan antar kelas seperti pertandingan voli, sepakbola, takraw dan masih banyak lagi. Jadi mereka tidak hanya fokus dalam kegiatan hafal-menghafal Alquran. Dengan begitu mereka bisa menikmati proses belajar umum mereka dengan tidak menghambat tujuan awal.

Di bidang seni pesantren ini juga ikut andil dalam menyukseskan acara MTQ baik tingkat pesantren sampai provinsi. Meski belum bisa merai prestasi dibidang ini. Tetapi, semangat para santri selalu terpancar dengan semangatnya mereka selalu mengikuti perlombaan setiap tahunnya. Para santri dan santriwati selalu selalu berusaha untuk memberikan yang terbaik untuk pondok tercinta. 
Akan tetapi mereka tetap optimis dengan tujuan utama mereka di sekolahkan di pondok pesantren ini. Jadi para Ustaz atau Ustazah memberikan fasilitas dengan semaksimal mungkin terhadap santri dan santriwatinya.

Apabila ada seorang santri yang kelihatanya belum merasa nyaman belajar, serta sering ketakutan ataupun merenung, biasanya oleh Ustadz dan Ustazah selalu memotivasi bahwa dengan belajar menghafal Alquran adalah sebagai salah satu wujud kecintaan seorang anak terhadap orang tuanya. Namun motivasi dari orang tua adalah yang paling utama.

Disamping metode pengelolaan kelas merupakan suatu usaha yang dilakukan oleh penanggung jawab kegiatan belajar mengajar. Sebagai penunjanng pembelajaran tahfiz, Pesantren Tahfizul Quran menghias setiap kelas dengan tulisan-tulisan dan gambar-gambar yang berisikan motivasi dan semangat belajar santri, serta terdapat tulisan kaligrafi ayat-ayat suci Alquranyang dibuat oleh santri-santri sendiri, supaya sering dibaca dan menambah daya ingatan hafalan santri. Di samping itu jumlah santri perkelas sangat standar, sehingga para guru mudah untuk mengendalikan keaadaan kelas.

Selain itu ada yang perlu diperhatikan adalah pendekatan, pembelajaran tahfiz tidak selalu dengan suasana tegang, selalu duduk rapi di atas kursi, mereka bisa melakukan kegiatan belajar dengan duduk di lantai atau lesehan. Bahkan sering menghafal di luar bersama-sama di luar ruangan (ruangan terbuka). Hal ini dilakukan agar anak lebih senang untuk menghafal. Sebagaimana yang telah disampaikan oleh para guru tahfiz yang mengatakan bahwa yang terpenting menciptakan suasana yang enak ketika santri yang lelah dan capek sehingga sesekali perlu menciptakan permainan, jadi tidak harus cepat yang penting gairah santri untuk menghafal selalu muncul, karena kemapuan santri itu berbedabeda. Menyempurnakan mekanisme dan metode yang diterapkan oleh guru tahfidz. Salah satu faktor yang mendukung seseorang lebih mudah dan lebih cepat dalam menghafal Alquranadalah penggunaan metode yang tepat dan bervariasi. Hasil hafalannya pun tidak mudah lupa (Al-Bukhari, juz 3, h. 233). Sebagaimana diketahui, Alquran yang telah dihafal mudah hilang dari ingatan. Untuk itu, menjaga hafalan lebih berat daripada menghafalnya. Rasulullah Saw bersabda : "Peliharalah hafalan Alquran, sebab demi Dzat yang menguasai jiwa Muhammad, Al- Qurean itu lebih cepat terlepas daripada unta yang terikat dalam ikatannya "(Muttafaq Alaih) (Hidayah, 2016: 73-74).

"Saya lebih suka menghafal di luar ruangan karena udaranya lebih segar dan membuat saya lebih tenang tidak terganggu dengan teman-teman yang juga menghafal." Jawab Muhammad Ihsan (santri) yang duduk di bawah pohon dengan Alquran ditangannya.

Santri yang tidak bisa mencapai target dimotivasi agar disiplin dalam mengatur waktu, dan fokus pada hafalan Alquran. Sedangkan prestasi dalam bentuk penampilan dalam lomba ataupun event-event ataupun audisi seperti di televisi, selama ini tidak di wajibkan. Yang dicari dari menghafal Alquranbukan untuk ditampilkan mencari juara, tetapi lebih kepada bagaimanah mencintai Alqurandengan baik dan benar (Abas, 1993: 45).

Ketika setoran hafalan, apabila ada kesalahan (misalnya bacaan ataupun tajwid) wajah santri colekan "blauw" ini bukan berarti sebuah hukum atau pemberian sanksi kepada santri, tetapi lebih kepada mengingatkan beberapa kaili melakukan kesalahan yang harus diperbaiki. 
Dengancara itu santri bukanya patah semangat ataupun malu, tetapi diterima dengan senang dan tetap selalu ceria dan semangat. Di samping itu, santri yang satu dengan lainnya akan saling mengingatkan. Untuk menghindari banyaknya kesalahan, maka sebelum setoran ke Ustadz atau Ustadzah terlebih dahulu saling setor kepada teman-temannya. Dalam setoran apabila sudah tidak menunjukkan kesalahan atau kekurangan maka santri akan melanjutkan hafalan pada surat berikutnya. Sehingga bisa menambah hafalan jika sudah menyetor hafalan sebelumnya kepada Ustadz atau Ustazah.

Membaca dan menghafal berulang kali memberikan penguatan terhadap ingatan santri sehingga memudahkan santri dalam menghafal dan menjaga hafalannya. Pengulangan tersebut di sebut dengan rehearsal merupakan upaya untuk memasukkan ayat-ayat akan sedang di hafal kedalam ingatan jangka panjang sehingga hafalan tersebut dapat bertahan lama. Sebagaimana dijelaskan dalam proses mengingatkan bahwa informasi yang tersimpan dalam ingatan jangka paanjang akan bertambah lama tersimpan dalam jangka panjang akan bertahan lama dalam ingatan (As Sirjani, 2013).

Motivasi menjadi seorang hafizh untuk mengurangi dosa, karena diyakini bahwa setiap bacaan 1 ayat bisa mendapakatkan 1 pahala. Seseorang yang dapat menghafalkan dan mejaga keutuhan Alquran jika meninggalkan akan dijaga dari apapun, dan kalau meninggal akan mengurangi dosa. Keberkahan Alquran adalah dengan menjaganya melalui hafalannya Quran akan menolong 7 turunan masuk surga.

"Dalam menghafal Alquran bukan banyaknya hafalan yang dikejar tapi nikmat dari menghafal Alquran itu yang harus dirasakan. Dulu memang merasa terbebani tapi sekarang baru terasa betapa senang dan bahagia bisa menjadi bagian dari penghafal Alquran. Itu merupakan nikmat yang luar biasa." Ucapnya dengan senyum sumringah (Aldi Mustafa sebagai Alumni)

Artikel ini menunjukkan bahwa motivasi dari sang guru tahfidz yang selalu mendampinginya sangat dibutuhkan oleh santri. Orang yang menghafal Alquransangat mudah bosan dan lelah. Oleh karena itu, diperlukan motivasi utamanya dari guru yang membimbingnya. Motivasi bisa dilakukan dengan memberikan semangat yang menggugah, memberikan pujian dan penghargaan, memberikan cerita para hafidz/hafidzah yang sukses setelah melakukan perjuangan menghafal Alquran.

\section{Simpulan}

Lingkungan di sekitar Pondok Pesantren Tahfizul Qur'an Sungai Pinang adalah masyarakat petani. Animo masyarakat terhadap Pesantren Tahfizul Qurean Sungai Pinang sangat tinggi sehingga pada setiap tahun ajaran baru banyak para orang tua memasukkan anak nya ke Pesantren Tahfizul Qur'an. Metode Tahfizul Qur'an. Pesantren Tahfizul Qur'an menggunakan metode talaqqi, maksudnya adalah santri membaca Alquran dihadapan ustadz sampai ucapannya benar. Setelah benar barulah santri tersebut menghafalnya sendiri.

Metode Tahfizul Qur'an menggunakan metode talaqqi, maksudnya adalah santri membaca Alquran dihadapan ustadz sampai ucapannya benar. Setelah benar barulah anak tersebut menghafalnya sendiri. Di Pesantren Tahfizul Qur'an waktu yang baik untuk menghafal Alquran adalah di pagi hari sebelum kegiatan yang lain dimulai, misalnya jam 
06.00 sampai jam 07.00. Serta mengulang hafalan setelah selesai shalat fardhu untuk mempelancar hafalan ayat. Motivasi menjadi seorang hafizh untuk mengurangi dosa, karena diyakini bahwa setiap bacaan 1 ayat bisa mendapakatkan 1 pahala. Seseorang yang dapat menghafalkan dan mejaga keutuhan Alquran jika meninggalkan akan dijaga dari apapun, dan kalau meninggal akan mengurangi dosa. Keberkahan Alquranadalah dengan menjaganya melalui hafalannya Quran akan menolong 7 turunan masuk surga.

\section{Referensi}

Abas, M. Ziyad. (1993). Metode Praktis Menghafal Alquran. Jakarta: Firdaus.

Ahsin, W.Al Hafidz. (2004). Bimbingan Praktis Menghafal Alquran. Jakarta : Bumi Aksara.

Alawiyah, Iffah. (2004). Efektifitas Penghafalan Al-Qur'an (Studi Kasus di Pesantren AnakAnak Yanbu' al-Qur'an Krandon Kudus Jawa Tengah). Skripsi. Semarang: Fakultas Tarbiyah Institut Agama Islam Negeri Walisongo.

Al-Bukhari. Shahih al-Bukhari, juz 3.

Al-Umar, Nashir bin Sulaiman. (2009). SMS Tadabbur Al-Qur'an. Surabaya: Pustaka ELBA. Fachrudin, Yudhi. (2017). Pembinaan Tahfizh Al-Quran Di Pesantren Tahfizh Daarul Qur'an Tangerang,Jurnal Kordinat, 16(2), 325-348.

Hafidz, Ahsin W. (2004). Bimbingan Praktis Menghafal Alquran. Jakarta: Bumi Aksara.

Hamam, Hasan bin Ahmad bin Hasan. (2008). Menghafal Alquran Itu Mudah. Jakarta: AtTazkia.

Hidayah, N. (2016). Strategi Pembelajaran Tahfidz Al-Qur'an di Lembaga Pendidikan, Ta'allum: Jurnal Pendidikan Islam, 4(1), 63-81.

Maghfiroh, Lailatul. (2009). Upaya Pondok Pesantren Wahid Hasyim Mengatasi Kejenuhan Santri dalam Menghafal Alquran Di Asrama MI Wahid Hasyim Gaten Condongcatur Depok Sleman Yogyakarta. Skripsi. Yogyakarta: Fakultas Tarbiyah dan Keguruan UIN Sunan Kalijaga

Saepudin, Juju. (2015). Membumikan Peradaban Tahfiz Al-Qur'an. Jakarta Timur: Balai Penelitian dan Pengembangan Agama Jakarta.

Sirjani, Raghib As. (2013). Cara Cerdas Hafal Al Qur'an. Solo: Aqwam.

Su'aib dan Muhammad. (2011). Lima Pesan Al-Qur'an. Malang: UIN Maliki Press.

Sugiono, Memahami Penelitian Kualitatif, (Bandung : Alfabeta, 2012), 94-95.

Zainu, Syaikh Muhammad Jamil. (2006). Bagaimana Memahami Al-Qur'an. Jakarta Timur: Pustaka Al-Kautsar.

Zuhri, Saefudin. (2005). Jujur Modal Kebahagian dan Keselamatan Dunia Akhirat. Jakarta Selatan: Pustaka Azzam. 